\title{
Knowledge of nursing students on dysthanasia
}

\author{
Conhecimentos de estudantes de enfermagem sobre distanásia
}

\section{Conocimientos de estudiantes de enfermería acerca de la distanasia}

\author{
Mariana Costa Matos ${ }^{1}$, Darci de Oliveira Santa Rosa, Karla Ferraz dos Anjos
}

Objective: to evaluate the knowledge of nursing students about the dysthanasia as a process of human intervention in terminally ill patients. Methods: a qualitative study with 28 nursing students from a public higher education institution. Data analysis of the interviews was through thematic content analysis. Results: it was found that most students do not understand the meaning of dysthanasia, though living with situations involving this practice in their training. Those who defined the term described it as the excessive prolongation of life or death suffered from much pain, aggressive treatment that only prolongs the process of dying. Conclusion: it was evidenced that nursing students have insufficient knowledge of the dysthanasia and it is necessary to broaden the discussion spaces during the graduate course and conduct studies on the subject relating it to the death and dying process, for the preparation of future health professionals.

Descriptors: Students, Nursing; Knowledge; Medical Futility; Terminal Care; Death.

Objetivo: avaliar os conhecimentos de estudantes de enfermagem sobre a distanásia como processo de intervenção humana em pacientes terminais. Métodos: estudo qualitativo, realizado com 28 estudantes de enfermagem de uma Instituição de Ensino Superior pública. 0 tratamento dos dados das entrevistas foi efetuado por meio da análise de conteúdo temática categorial. Resultados: verificou-se que maioria dos estudantes não compreende o significado da distanásia, apesar de conviver com situações que envolvem esta prática em seus campos de estágio. Aqueles que definiram o termo descreveram como prolongamento excessivo da vida ou morte sofrida, com muita dor, tratamento agressivo que somente prolonga o processo de morrer. Conclusão: evidenciou-se que estudantes de enfermagem apresentam conhecimentos insuficientes sobre a distanásia e há necessidades de ampliar os espaços de discussão na graduação e a realização de estudos sobre a temática relacionando-o ao processo de morte e morrer, com o propósito de preparo dos futuros profissionais de saúde.

Descritores: Estudantes de Enfermagem; Conhecimento; Futilidade Médica; Assistência Terminal; Morte.

Objetivo: evaluar conocimientos de estudiantes de enfermería sobre distanasia como proceso de intervención humana en pacientes terminales. Métodos: estudio cualitativo, con 28 estudiantes de enfermería de una institución de educación superior pública. Análisis de datos de las entrevistas se realizó a través del análisis de contenido temático. Resultados: la mayoría de los estudiantes no entienden el significado de la distanasia, aunque conviven con situaciones de esta práctica en sus campos de entrenamiento. Los que definieron el término, describieron como prolongación excesiva de la vida o muerte sufrida con mucho dolor, tratamiento agresivo que sólo prolonga el proceso de morir. Conclusión: los estudiantes de enfermería presentaron conocimientos insuficientes sobre la distanasia y es necesario ampliar los espacios de discusión en posgrado y realización de estudios sobre el tema, relacionándolo con la muerte y el morir, con finalidad de preparación de los futuros profesionales de la salud.

Descriptores: Estudiantes de Enfermería; Conocimiento; Inutilidad Médica; Cuidado Terminal; Muerte.

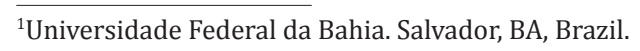




\section{Introduction}

Health professionals, especially those working in hospital services, are continually exposed to situations that deal with the death of people they assist.

Despite the frequent contact with death among the nurses, it is observed that they have difficulties to express feelings associated with the process of dying, especially when related to death, considered a phenomenon that causes deep emotional changes in people ${ }^{(1)}$. This scenario is not different when it comes to nursing students who need to deal with death or caring for a terminally ill patient during their practice and training ${ }^{(2)}$.

The terminally ill patient sees death as inevitable and predictable by his irreversible disease and by the lack of possibilities of not rescuing his health conditions. For these patients, palliative treatment is usually indicated to alleviate suffering and offer comfort. However, due to the timing of the end of his life, discussions on the subject and appropriate behaviors to relieve pain and suffering of the people are necessary ${ }^{(3)}$. For this reason, therapeutic obstinacy is an increasingly explored subject in the context of a terminal or palliative care.

Palliative care is offered to people in the early stages of progressive, advanced and incurable diseases. The transit in conventional and biotechnology treatments, protects against the disease and allowing assistance modifications. The care extends the symptoms control to assist the patient in a psychosocial and spiritual dimension, as well as their families. This care proposes listening to patients, protection and care, enabling healthcare professional touching them and being touched ${ }^{(4)}$.

A study shows that the lack of preparation of nursing students towards issues related to human finitude is worrisome because it contributes transforming death into something less natural and more suffering ${ }^{(5)}$. This scenario grows discussions on the commitment of health professionals, especially nurses, who have more direct and frequent contact with the terminally ill, with the defense of human dignity until the moment of his death.

In an attempt to change this reality, it is essential to reflect the students and future health professionals about patient care in their life cycle, particularly patients who experience the death and dying process. Nursing students need to be encouraged to know the different types of care at the end of life, to preserve the dignity and quality of life of these patients until the time of their death ${ }^{(6)}$.

Dysthanasia is understood as excessive investment to extend the life of the people and a long, slow death and often, accompanied by suffering, pain and agony ${ }^{(7)}$. This practice can be considered futile or useless treatment, without benefits for the person in his terminal phase, where death and dying process is merely prolonged and not exactly his life $\mathrm{e}^{(8)}$.

Concern about the quality and not the quantity of life is essential because this death should not be understood as a gap of medical competence or even failure. First, it is a condition of human existence, an integral part of people's lives, as natural as birth. It is necessary to admit that in some situations, to cure is not possible even with the scientific and technological development that led to the exploitation of medicine and medicalization of death ${ }^{(9)}$.

Based on the above, it is important to understand the process of prolongation of life in different social contexts and available technology. However, dysthanasia as a care modality appears as a relevant ethical problem, especially in contemporary times, in which the technical and scientific progress began to intervene decisively in human life and in particular in the terminal phase.

It is clear that patients with no hope of recovery should receive comfort and attention by the health team for their physical, psychological, social and spiritual needs. In some circumstances, the use of technology to extend the life imposes further suffering to patients and their families and represent unnecessary expenses ${ }^{(10)}$. 
In this perspective, when health professionals have theoretical knowledge during training on topics abut the death and dying process, they favor the conscious and responsible form of comprehensive care directed to the demands of patients in terminal situations and their families. A study ${ }^{(11)}$ showed that even with the complexity and magnitude of these topics, little has been explored in nursing degree, even recognizing that this influences in comprehensive, humanized, efficient and effective care at every stage of the life cycle.

This study aims to evaluate the knowledge of nursing students on dysthanasia as a human intervention process in terminally ill patients.

\section{Method}

A qualitative study, conducted with students of eighth and ninth semesters of an undergraduate degree in nursing from a public higher education institution in the city of Salvador, Bahia, Brazil. The institution had 110 nursing students enrolled in the semesters mentioned above. Of these, 28 students participated in this study, through random probability sampling, and the collection ended after checking the theoretical saturation of data. All students had the same probability of being interviewed. The selection of the semester was to recognize that students have more opportunity during the course to a have theory about dysthanasia and have experienced situations of it during internship practice.

The data collection instrument was an interview script containing 11 questions related to the knowledge of nursing students about the care of the person in the death and dying process, with questions about dysthanasia, euthanasia and orthothanasia. For this study, the answers related to the following question were used: what does dysthanasia mean for you?

The interviews were conducted between 2011 and 2012 by volunteer nursing students and internship research students, with an average duration of 18 minutes each (for all inquiries) and carried out in areas of the Higher Education Institution where the study participants were enrolled and in places where they performed their curricular practical activities. The time and place of the interviews were scheduled in advance with the study participants, according to their preference and according to their availability.

Inclusion criteria were being over 18, being regularly enrolled in Higher Education Institution in the eighth and ninth semesters of the nursing course. Those who agreed to participate had their answers recorded, transcribed and safeguarded in the database of the researchers for further analysis.

Interviews data were analyzed using thematic content analysis that aims to get through systematic and objective procedures to describe the content of the messages and indicators that allow the inference of knowledge related to the conditions of production/ reception of these messages. This process consisted of three stages: a) Pre-analysis, an organization of reading material; b) operating the material for successive readings of the material transcribed to apprehend themes that emerged and thus building a table with objectives to systematize the information that led to the categorization of knowledge. c) Data processing for the construction of themes for further inference $^{(12)}$.

Each student was identified in their speech by NS vowels (nursing student) followed by the number of interview order to ensure the anonymity of the participants in the dissemination of results.

This study was approved by the Research Ethics Committee of the Federal University of Bahia School of Nursing in the opinion number 18/2011.

\section{Results}

The study included 28 nursing students, and 27 of them were female. The age ranged from 21 to 29 years old. They were asked about the meaning of dysthanasia, and from the collected material, two empirical categories emerged: student's knowledge 
about the term of dysthanasia and the nursing student experience on dysthanasia when caring for patients, presented below.

\section{Category 1: Student's knowledge about the term of dysthanasia}

This category shows the knowledge of students about dysthanasia. There were 24 of the participants expressing they do not have a knowledge or do not remember about its meaning. While claiming not to remember, they recognized to work already at some point during their undergraduate studies. However, they failed to form a concept of it. This can be linked to the fact that dysthanasia, euthanasia and orthothanasia have similar meanings since they were also asked about these terms to the study participants and created confusion between their meanings.

Among the four students who formulated some definition about dysthanasia, they defined it as the artificial prolongation of the terminal person's life and the use of techniques and equipment in the process, such as mechanical ventilation, as evidenced in the following speech: Dysthanasia is to prolong the most of one's life. Inserting new methods to continue living (NS 3). It is to prolong artificially life (NS 2).... It's just prolonging at all costs the life of the person (NS 5). ... It would be extending the life of that person, with mechanical ventilation devices. The person is only running for those devices (NS 5). Dysthanasia is with the advancement in technology, you prolong this life artificially, and when artificially prolonging life, you generate pain and suffering in the process for that person (NS 2).

\section{Category 2: The nursing student experience on dysthanasia when caring for patients}

Although they were not asked about their experience of terminally ill patient care in the practice fields, there was a speech that expressed his patient care experience subjected to excessive prolongation of life in the dying process. As expressed in the speech: Today there is a patient in the hospital. Every time I'm going to perform aspiration because he has a lot of secretion, it is very hard for me to see how his body reacts to it, how it's hard to see. It was very hard and suffering for that person. For me it was very suffering and how hard it was for his family. And how hard it was for me that (NS 4).

The student demonstrates the impact when secretions aspiration from a patient in his terminally stage with body reactions, even though the patient does not express in words his discomfort. This suffering lived in the hospital was described as difficult to him as being who cared and the family present in the unit.

It is noteworthy that not all nursing students in their internships have a clinical opportunity to care for patients at risk and/or situations of dysthanasia, by not always happen in practice or during the short period in touch with the acting sector. This may explain the lack of testimonials about the meaning of dysthanasia. However, even not experiencing these situations, knowledge of the subject is essential in the practice of students and nurses because they live with situations involving the death and dying process of people they take care.

\section{Discussion}

Dysthanasia is a process that leads to the artificial extension of life beyond what it would be the biological and avoid death ${ }^{(8)}$. In this context and known by the students, it is observed that the dying process is extended and not exactly a person's life. This practice is also known as "therapeutic obstinacy" or "medical futility" in which everything needs to be done, even without any benefit to the person in the terminal phase ${ }^{(13)}$. This concept could be confirmed by the results of this study to emphasize the obstinacy extension of people's life, with the possibility of the existence of ethical dilemmas.

This ethical dilemma in the practice of health professionals can be expressed in questions like: to what extent the process of dying and death should be prolonged when there is no hope of life? By denying human finitude ${ }^{(14)}$, motivated by the moral to preserve life, some professionals use therapies to prolong the death of people, to ensure the care in health and save 
lives. However, there are professionals who argue for the discontinuation of treatment due to the lack of quality of life. Thus, ethical and moral dilemmas are expressed in their daily lives.

Despite the difficulties to dysthanasia, all agreed that the basis for the judgment to this issue needs to be the benefit of the patient, where the proportionality between the benefit and utility needs to be decisive and consider the principles of beneficence and non-maleficence ${ }^{(14)}$. Also, respecting the autonomy of the patient, as this is important for determining therapeutic approaches to be employed.

Continuing in a treatment considered futile and painful is against the fundamental principles of medical ethics: beneficence because it does not provide benefit to the patient; non-maleficence because it can cause pain and injury to the patient; against justice, since it requires cost, time and energy that could be used in other patients; and against the autonomy because people do not want to receive a futile therapy to extend simply death for hours or days (inevitable) in an irreversible vegetative state without adding quality of life ${ }^{(15)}$.

The nurse plays an important role in ensuring the exercise of autonomy of patients under their care. This is because the practice can only be considered full when guarantying information on its truth to the relatives and patients in an accessible language so that they can take appropriate, free and conscious decisions ${ }^{(8)}$.

The Nursing Professionals Ethics Code defines responsibility and nurse's duty to collaborate with the health team in clarifying the person, family and community about the rights, risks, benefits and complications about their health and treatment. However, this Ethics Code does not address the responsibilities, duties and prohibitions of nurses in situations involving dysthanasia. It deals only in Article 29 of euthanasia, which expressly prohibits this professional to promote euthanasia or to participate in practice designed to anticipate the customer's death, on pain of suspension and/or revocation of the right to professional practice ${ }^{(16)}$.

The health professional is bound ethically and legally to perform dysthanasia actions in cases of patients diagnosed with brain death, in which his legal representative has authorized the donation of organs for transplant, or even when after due clarification from the professional family deems necessary to carry out such procedures ${ }^{(17)}$.

The Medical Ethics Code has as its fundamental principle of medical practice that in irreversible and terminal medical conditions, doctors should avoid performing unnecessary diagnostic and therapeutic procedures and allow the patients under his care all appropriate palliative care. In Article 41, sole paragraph provides that in cases of patients with incurable and terminal illnesses, the medical professional must offer all palliative care available without undertaking diagnostic actions or therapeutic useless or obstinate, and always consider the wishes of the patient and, when not possible, from the legal representative ${ }^{(17)}$.

In the precepts of the medical ethics code, the purpose of medicine is not only maximizing the person's lifetime. Among the fundamental principles of the profession, there is the practice of medicine keeping absolute respect for the human being and acting on their behalf, a criterion that needs to be considered when evaluating the procedures to be employed ${ }^{(17)}$.

The Charter of Rights of the Health Users clarifies that a person such as citizen of rights, may, after obtaining information, consent or decline in a free, voluntary and informed diagnostic procedures, preventive or therapeutic, unless this entails risks to public health. Added to this, it states that people have the right to choose the place of their death and if they want to return to their homes to die in a way they think is more dignified and human ${ }^{(18)}$.

On the legal context surrounding dysthanasia, in Brazil, there is no more specific legislation regarding this issue. This fact becomes even the decision-making process more complex to the withdrawal or not of the 
terminal patient life support, increasing anguish and uncertainty experienced by health professionals.

Therapeutic obstinacy happens when there are no more chances of cure and still keeps all medical interventions. This situation has become increasingly common in recent years mainly due to advances in medicine, because, through it, it has been possible to maintain the survival of critically ill patients for long periods in hospital admissions units, with life-support measures and technological devices ${ }^{(15)}$. The use of medical technologies for maintaining and prolonging thelife of terminal patients were identified. The student adds the concept of dysthanasia the functioning of the human body in the process of death by the use of instruments such as mechanical ventilation device.

It is observed that technological advances allow the cure of several diseases. However, the did not prevent the death of people. The more equipped technological resources for the institution or society, it most likely occurring dysthanasia practices. Therefore, it is essential to reflect on the use of systematic and critical was of these resources at the end of life. This is because the cure, typical of technoscience, ignores the suffering as complex feeling. And despising this approach is to minimize human life to physiological dimension; as well as allowing the therapeutic intensification in the belief that relieve pain is to relieve the suffering of those who live $\mathrm{e}^{(9)}$.

Therapeutic obstinacy is considered a medical attitude aimed at saving the life of terminal patients. However, submitting him to the suffering. Among the students, it is possible to identify the understanding of dysthanasia as a form of cruel, slow, prolonged death and often, accompanied by suffering and agony. The student associates the meaning of dysthanasia to the use of technology to prolong life artificially monitored for pain and suffering that this procedure causes to the person.

The dictionary Aurélio also brings this concept when defining dysthanasia as a slow, anxious death and with much suffering ${ }^{(19)}$. Incipient understanding of the meaning of this term refers to reflection on the process of training during graduation, since the lack of knowledge hampers the exploitation for professional performance in terminal situations. Among students, dysthanasia involves a practice in which excessively use of technological devices to prolong the dying process of patients without therapeutic possibilities of cure, leading him to suffer, pain, and agony.

The results of this study showed that most nursing students are unaware of the term dysthanasia and the minority has an incipient knowledge. These data are corroborated in part by the study ${ }^{(8)}$ developed with nurses, in which $65.3 \%$ said that in their daily practice there are dysthanasia (82.3\%), orthothanasia (52.9\%), and euthanasia (11.7\%). Concerning dysthanasia, $54.5 \%$ of these professionals understand this term as extending the life artificially and without benefits for the patient; $9.1 \%$ associated with the slow death and suffering, and $36.4 \%$ did not answer the question and admitted not knowing or conceptualized it incorrectly ${ }^{(8)}$. This shows that many students and nurses have incipient knowledge on the subject.

By analyzing the curriculum of the nursing course of the higher education institution in which this study was conducted, after its authorization and considering the current matrix for these students during the period of their admission to the course, it was observed that discussions on this issue took place in the fourth quarter, during Nursing Practice subject. In other words, the issue is addressed, however, in isolation and only in one subject during graduation. This may be related to most of lack of knowledge of nursing students about dysthanasia. This finding reaffirms the lack of spaces for discussion and reflection that provide the student gain understanding about death and its implications in nursing care to terminally ill patients.

As seen, although in the institution where this study was conducted there is a subject that deals with topics about the process of death and dying in undergraduate nursing, it is noted that the content 
is not incorporated in a cross-sectional way. A study shows that there is no preparation of nursing students on the topic ${ }^{(2)}$ and one study ${ }^{(11)}$ shows that most nurses report that during their graduation there was no content or subject about this theme, reflecting on the professional performance with patients in death situations, and their essential increase in training to support students and health professionals in care.

Given the terminally ill patient with no chance of cure, it is evident the suffering and helplessness of nursing students when they experience the patient care in dysthanasia situation. Feelings such as fear of death, suffering, and pain, in a real situation from the initial nursing education, still needs to be worked in graduation. These results are similar in part to studies developed with nursing professionals who describe feelings like sadness, shame, surprise, distress ${ }^{(1)}$, impotence, loss, frustration and anxiety in the professional context and staff, witnessing the death of a patient especially unexpectedly. Nurses reported that at the moment of death raises many emotions and reactions because it brings the memory of one's finitude. These feelings are minimized by the experience gained in years of service ${ }^{(11)}$.

Although nursing professionals live in their practice with the process of dying and death, they struggle with these situations and, in most cases, they prefer to avoid involvement in the care of patients and their families to preserve their mental health. Dealing with death is a complex task among health professionals, so invest in strategies that encourage reflection on human existence is fundamental ${ }^{(1)}$. In this context, it is noted that the preparation of students in the health field during graduation to face death and dying situations is necessary, especially on today technological and scientific advances.

Dysthanasia is a recurring situation in every day of clinical nurses. Thus, having knowledge of it reflected in their behavior in the different moments of the evolution of the clinical condition of the patient, not doing or collaborating with some dysthanasia measure, adding suffering to people who are in the process of dying ${ }^{(8)}$. When the nurse is aware of this term and reflects on it in every moment of the process of dying of the patient, this may assist in the discussions of the interdisciplinary team, patient and family, promoting quality care ${ }^{(20)}$.

In addition, it is essential that nurses participate in decision-making processes to the procedures for assistance, so they can identify situations where the bioethical principles and patients' rights are not being respected and make necessary interventions, providing humanization warranty and security ${ }^{(8)}$.

\section{Conclusions}

The results showed that few nursing students understand the meaning of the term dysthanasia and those who formed a concept of this term did it superficially, despite living with situations involving this practice in their internship.

The lack of knowledge students demonstrated is worrying, because soon, they will be taking responsibility as nurses in homes and hospitals and providing care to terminally ill patients. This can influence the decision-making process of these professionals and sometimes accompany the process of death of these patients suffered a care practice more painful and difficult, as demonstrated by students.

It is understood that conceptualize comprehensively the term dysthanasia is not easy, considering its complexity. However, nursing students need to be prepared to deal with these situations in their practice environments, since as nurses they may come across these situations. Thus, meeting on the issue is critical and promotes professional acting consciously, fully and responsibly directed to the needs of dying patients and their families.

The need to expand the spaces for discussion and studies on dysthanasia from nursing degree is highlighted, since actions such as these influence the acquisition of knowledge and behavior of future 
nurses who provide care to terminally ill patients, and in this way, they may identify situations that prolong life and conditions that generate suffering to people.

This study has limitations because it was carried out only in a public higher education institution. It is recommended that further research on the human intervention in the death and dying process are developed with students so that they identified their knowledge and they may be related to bioethical principles, nursing care in terminally life and the vocational training process.

\section{Collaborations}

Matos MC helped in the design, collection, analysis and interpretation of data, article writing and final approval for publication. Santa Rosa DO participating in orientation, analysis and interpretation of data, article writing and final approval. Anjos KF contributed on the writing, critical review and end of the article.

\section{References}

1. Mattos TAD, Lange C, Cecagno D, Amestoy SC, Thofehrn MB, Milbrath VM. Profissionais de enfermagem e o processo de morrer e morte em uma unidade de terapia intensiva. Rev Min Enferm. 2009; 13(3):337-42.

2. Santos JL, Bueno SMV. Death education for nursing professors and students: a document review of the scientific literature. Rev Esc Enferm USP. 2011; 45(1):272-6.

3. Nogueira FL, Sakata RK. Sedação paliativa do paciente terminal. Rev Bras Anestesiol. 2012; 62(4):580-92.

4. Burlá C, Py L. Cuidados paliativos: ciência e proteção ao fim da vida. Cad Saúde Pública. 2014; 30(6):1139-41.

5. Felix ZC, Costa SFG, Alves AMPM, Andrade CG, Duarte MCS, Brito FM. Eutanásia, distanásia e ortotanásia: revisão integrativa da literatura. Ciênc Saúde Coletiva. 2013; 18(9):2733-46.
6. Sanchez KMS, Seidl EMF. Ortotanásia: uma decisão frente à terminalidade. Interface Comunic Saúde Educ. 2013; 17(44):23-34.

7. Junges JR, Cremonese C, Oliveira EA, Souza LL, Backes V. Reflexões legais e éticas sobre o final da vida: uma discussão sobre a ortotanásia. Rev Bioét. 2010; 18(2):275-88.

8. Biondo CA, Silva MJP, Secco LMD. Dysthanasia, euthanasia, orthotanasia: the perceptions of nurses working in intensive care units and care implications. Rev Latino-am Enfermagem. 2009; 17(5):613-9.

9. Freio AGO, Oliveira CC. Responsabilidade e tecnologia: a questão da distanásia. Rev Bioét. 2011; 19(3):615-30.

10. Pessini L. Distanásia: por que prolongar o sofrimento? Rev Ciênc Hoje. [Internet] 2013 [citado 2014 abr 30]. Disponível em: http:// cienciahoje.uol.com.br/revista-ch/2013/301/ distanasia-por-que-prolongar-o-sofrimento

11. Lima MGR, Nietsche EA, Teixeira JA. Reflexos da formação acadêmica na percepção do morrer e da morte por enfermeiros. Rev Eletr Enf. [Internet]. 2012 [citado 2014 abr 30]; 14(1):181-8. Disponível em: https://www.fen.ufg.br/revista/ v14/n1/pdf/v14n1a21.pdf

12. Bardin L. Análise de conteúdo. Lisboa: Edições 70; 2011.

13. Bottega C, Campos LSF. Considerações sobre eutanásia, distanásia e ortotanásia e a Bioética. Rev Jurídica Universidade Cuiabá. 2011; 13(2):3962.

14. Ferreira APJ, Souza LJ, Lima AAF. O profissional de saúde frente à distanásia: uma revisão integrativa. Rev Bioethikos. 2011; 5(4):462-9.

15. Santana JCB, Rigueira ACM, Dutra BS. Distanásia: reflexões sobre até quando prolongar a vida em uma Unidade de Terapia Intensiva na percepção dos enfermeiros. Rev Bioethikos. 2010; 4(4):40211.

16. Conselho Regional de Enfermagem da Bahia. Principais legislações para o exercício da Enfermagem. Código de Ética dos Profissionais de Enfermagem. Salvador: CRE; 2012. 
17. Conselho Federal de Medicina. A medicina para além das normas: reflexões sobre o novo Código de Ética Médica. 2010 [citado 2014 jun 26]. Disponível em: http://www.portal.cfm.org.br/ images/stories/biblioteca/a\%20medicina\%20 para\%20alm\%20das\%20normas.pdf

18. Ministério da Saúde (BR). Carta dos direitos dos usuários da saúde. Brasília: Ministério da Saúde; 2011.
19. Ferreira ABH. Dicionário Aurélio da Língua Portuguesa. Curitiba: Positivo, 2010.

20. Menezes MB, Selli L, Alves JS. Dysthanasia: nursing professionals' perception. Rev Latino-Am Enfermagem. 2009; 17(4):443-8. 